\title{
Rising Natural Gas Prices and Real Economic Activity
}

\begin{abstract}
Kevin L. Kliesen
In the aftermath of the disruptions caused by hurricanes Katrina and Rita, natural gas prices rose to record-high levels. Because natural gas is an important energy source for the U.S. economy, there was widespread concern that these high prices might cause a significant slowing in the economy—especially among those manufacturing industries that heavily consume natural gas. The analysis presented in this article suggests that output is responsive to natural gas prices in some manufacturing sectors. Although perhaps significant, this result must be balanced against the finding that, when the analysis is extended to the macroeconomy (real gross domestic product growth), increases in crude oil prices significantly predict real gross domestic product growth, but natural gas prices do not. (JEL Q41, Q43)
\end{abstract}

Federal Reserve Bank of St. Louis Review, November/December 2006, 88(6), pp. 511-26.

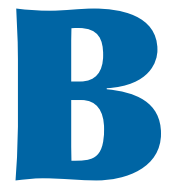

eginning in early 2002, prices of crude oil and natural gas began to trend upward. By September 2005, as the damage to the production, refining, and distribution facilities in the Gulf Coast by hurricanes Katrina and Rita became clearer, natural gas prices rose to record-high levels in both nominal and real dollar terms. Although crude oil prices rose to a record-high level in nominal terms, they remained below the recordhigh levels in real terms seen in early 1981. Previous research has shown that sharply higher oil prices have preceded all but one of the postWorld War II recessions. However, less is known about the relationship between rising natural gas prices and macroeconomic activity, despite the fact that many manufacturing industries and, increasingly, electric utilities are heavy consumers of natural gas. Accordingly, one might reasonably assume that record-high levels of natural gas prices might have significant adverse consequences for U.S. macroeconomic activity.

This article examines developments in natural gas prices and highlights recent trends in natural gas usage at both the industry and national levels. The article concludes with some empirical findings that generally suggest that rising natural gas prices predict growth in only a handful of manufacturing industries. Perhaps surprisingly, higher natural gas prices do not predict slower growth for the three industries where expenditures on natural gas are a relatively large share of total industry shipments: primary metals, nonmetallic mineral products, and chemicals. In terms of the aggregate economy, increases in crude oil prices significantly predict the growth of real gross domestic product (GDP), but increases in natural gas prices do not.

\section{TRENDS IN NATURAL GAS PRICES}

From 1954 to 1978, the price of natural gas transported through the interstate pipeline system was regulated by the Federal Power Commission. Under this system, price-setting was based on pro-

Kevin L. Kliesen is an economist at the Federal Reserve Bank of St. Louis. The author thanks Hui Guo, David Henry, and Crawford Honeycutt for comments and suggestions, and Joshua Byrge, John McAdams, and Joshua Ulrich for research assistance.

(C) 2006, The Federal Reserve Bank of St. Louis. Articles may be reprinted, reproduced, published, distributed, displayed, and transmitted in their entirety if copyright notice, author name(s), and full citation are included. Abstracts, synopses, and other derivative works may be made only with prior written permission of the Federal Reserve Bank of St. Louis. 


\section{Figure 1}

\section{Natural Gas Prices at the Wellhead}

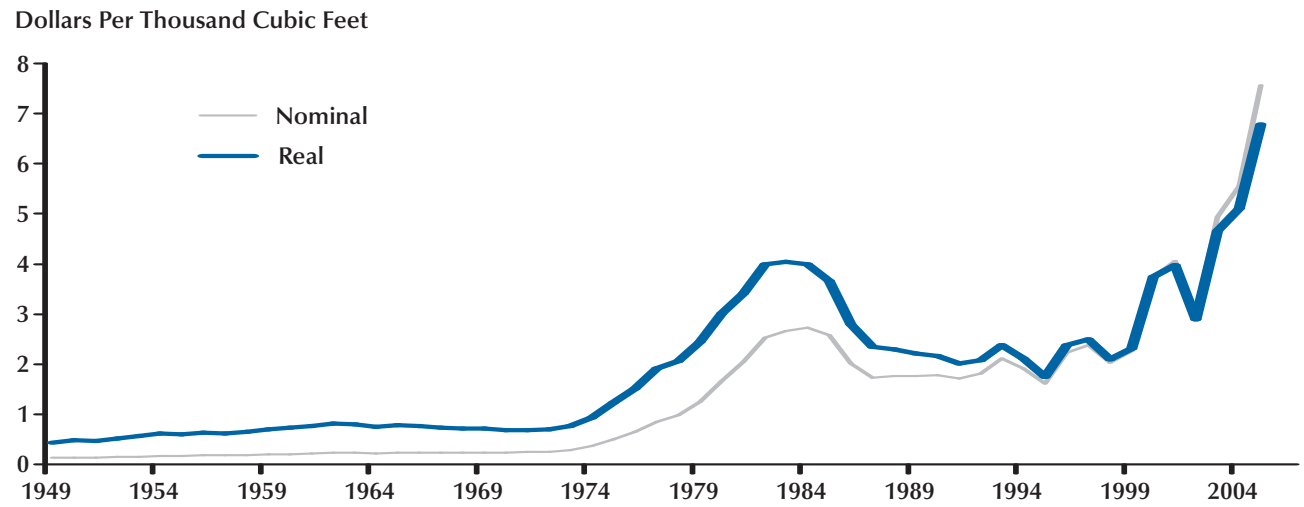

SOURCE: U.S. Energy Information Administration.

duction costs and applications for rate increases moved slowly through the bureaucratic process. ${ }^{1}$ As a result, prices changed very little from year to year. As seen in Figure 1, from 1949 to 1978, wellhead prices averaged $\$ 0.21$ per thousand cubic feet (mcf), with an annual standard deviation of $\$ 0.20$ per mcf. ${ }^{2}$ Although phased deregulation began with the passage of the Natural Gas Policy Act of 1978, prices began to rise in the mid-1970s, a period of turmoil in international energy markets that saw a sharp increase in crude oil prices. Eventually, natural gas prices peaked in 1984 at $\$ 2.66$ per mcf (nominal). Prices subsequently retreated modestly and then remained fairly stable for several years: From 1986 to 1999, natural gas prices averaged $\$ 1.87$ per mcf, with a standard

1 Yang (1977) and Ott and Tatom (1982b) discuss the history of natural gas regulation and deregulation.

2 The wellhead price is that received at the point of production (when the gas reaches the surface). According to the EIA, this price is calculated by dividing the total reported value at the wellhead by the total quantity produced. The latter is the amount reported by the appropriate agencies of individual producing states and the U.S. Mineral Management Service. The wellhead price includes all costs prior to shipment from the lease, including gathering and compression costs, in addition to state production, severance, and similar charges. See the glossary in the U.S. Energy Information Administration's Annual Energy Review 2004 (2005); e.g., "mcf" indicates one thousand cubic feet and one cubic foot is equal to 1,031 BTU; www.eia.doe.gov/kids/energyfacts/science/ energy_calculator.html\#natgascalc. deviation of $\$ 0.24$ per year. Following the 2001 recession, natural gas prices began to rise noticeably. By 2004, gas prices in both real and nominal dollars were at record-high levels.

In late August 2005, Hurricane Katrina made landfall near New Orleans, Louisiana, and then about one month later, Hurricane Rita made landfall near the Texas-Louisiana border. These two hurricanes caused significant damage to the Gulf Coast's production, refining, and distribution facilities. In response, natural gas prices surged. Over the first seven months of 2005, natural gas prices at the wellhead averaged $\$ 6.06$ per mcf. By August 30, a day after Katrina's landfall, prices in the spot market, which typically include a premium above the wellhead price, had surged pass \$12 per million British thermal units (BTU), and by September 22, 2005, the day before Rita's landfall, the spot price had risen to $\$ 15.00$ per million BTU. ${ }^{3}$ Over the final four months of the year, with a significant percentage of natural gas production in the Gulf still shut-in, the wellhead price averaged approximately $\$ 10$ per mcf.

Viewed from a slightly longer-term perspec-

3 In anticipation of Hurricane Rita's landfall, natural gas shipments to the Henry Hub, Louisiana, delivery point were suspended on September 23. Deliveries resumed on October 7. One thousand cubic feet of natural gas is approximately equal to 1 million BTU. 


\section{Figure 2}

\section{Energy Consumption by Major Source}

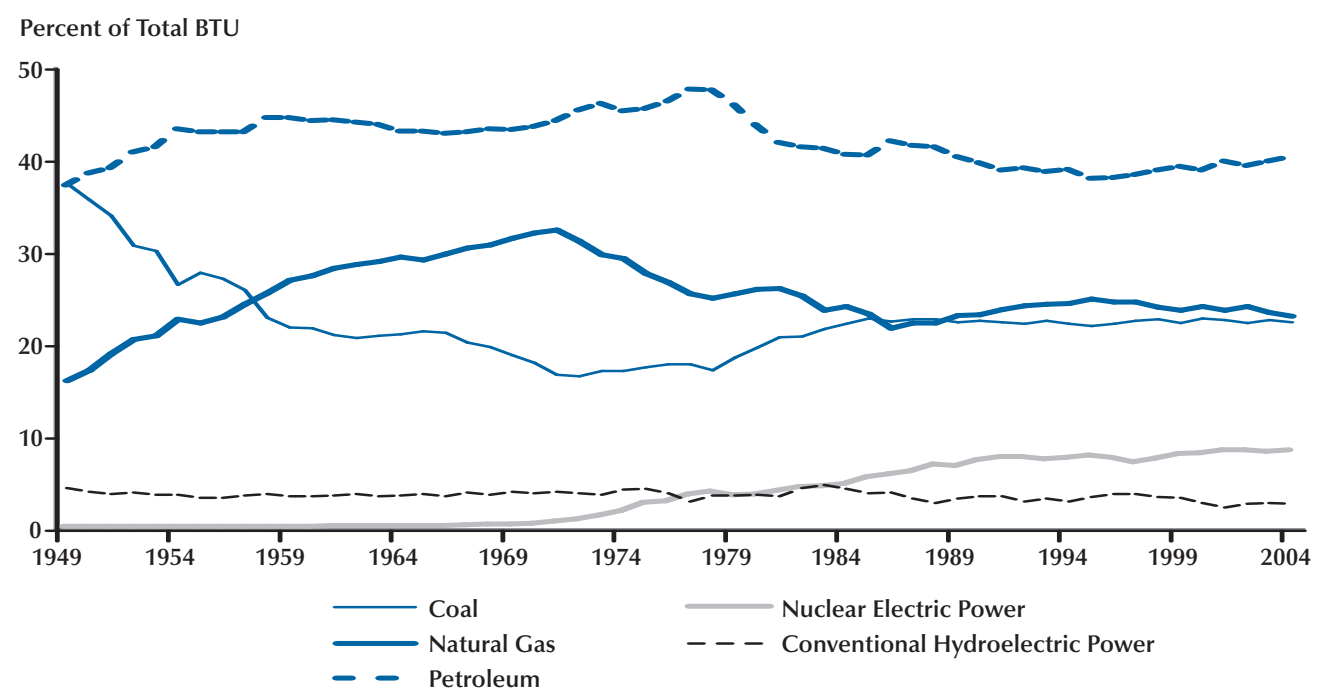

SOURCE: U.S. Energy Information Administration.

tive, the hurricanes exacerbated recent trends in higher natural gas prices. In their August 9, 2005, Short-Term Energy Outlook (pre-Katrina), the U.S. Energy Information Administration (EIA) noted several factors that were expected to keep natural gas prices at high levels over the near term:

The natural gas market is likely to stay tight over the next couple of months, with prices projected to rise further as the winter heating season increases demand. Although natural gas storage remains above the 5 -year average, several factors are expected to continue to support high natural gas prices, including: high world oil prices; continued strength in the economy; the expectation that Pacific Northwest hydroelectric resources will be below normal through the rest of the year; limited prospects for growth in domestic natural gas production; and concerns about the potential effects of hurricanes.

\section{U.S. NATURAL GAS CONSUMPTION}

Rising natural gas prices are a concern in the macroeconomy because many industrial and utility sectors are intensive users of natural gas and most households rely on gas to heat their homes during the winter months. In late 2005, anecdotal reports from the manufacturing sector suggested that high energy prices had indeed raised input costs and precipitated price surcharges among some industries. Examples of this nature were regularly cited in the Institute for Supply Management Report on Business for the manufacturing and nonmanufacturing sectors and in the Federal Reserve's "Beige Book." The purpose of this section is to quantify natural gas usage in the U.S. economy-both in comparison with other sources of energy and usage by sector.

Petroleum products remain the largest source of energy for the U.S. economy. As seen in Figure 2, 40.2 percent of U.S. energy consumption in 2004 (based on BTU) was derived from petroleum products such as oil, gasoline, and diesel fuel. Energy consumption derived from natural gas was the next largest source (23.1 percent), followed closely by coal (22.5 percent). The percentage of energy derived from natural gas consumption has been falling since 1971, when it peaked at nearly 32.4 percent of total BTU. By 1986, the percentage of total energy from 


\section{Table 1}

\section{Natural Gas Consumption by Sector}

\begin{tabular}{|c|c|c|c|c|c|c|}
\hline & \multicolumn{4}{|c|}{ End-use sectors ( $\%$ of total) } & \multirow[b]{2}{*}{ Total end use } & \multirow[b]{2}{*}{ Electrical power $\pi$} \\
\hline & Residential* & Commercial $^{+}$ & Industrial $^{\ddagger}$ & Transportation $\$$ & & \\
\hline 1950 & 20.8 & 6.7 & 59.4 & 2.2 & 89.1 & 10.9 \\
\hline 1960 & 25.9 & 8.5 & 48.2 & 2.9 & 85.6 & 14.4 \\
\hline 1970 & 22.9 & 11.3 & 43.8 & 3.4 & 81.4 & 18.6 \\
\hline 1980 & 23.9 & 13.1 & 41.2 & 3.2 & 81.5 & 18.5 \\
\hline 1990 & 22.9 & 13.7 & 43.1 & 3.4 & 83.1 & 16.9 \\
\hline 2000 & 21.4 & 13.6 & 39.8 & 2.8 & 77.7 & 22.3 \\
\hline 2004 & 21.9 & 13.4 & 37.7 & 3.1 & 76.0 & 24.0 \\
\hline
\end{tabular}

NOTE: *Consumption by private households. ${ }^{\dagger}$ Consumption by nonmanufacturing establishments. ${ }^{\ddagger}$ Consumption by establishments engaged primarily in processing unfinished materials into another form of product; this includes mining, petroleum refining manufacturing, and (beginning in 1996) agriculture, forestry, and fishing. ${ }^{\$}$ Natural gas transmission (pipeline) fuel and natural gas delivered for use as vehicle fuel. IElectric utilities and independent power producers.

SOURCE: U.S. Energy Information Administration, Annual Energy Review, 2004 (2005).

natural gas had fallen to just under 22 percent; however, it has since stabilized. Consumption of nuclear energy and conventional hydroelectric power sources are significantly smaller, both less than 10 percent of the total.

Table 1 details natural gas consumption in the economy by the four major end-use sectors (residential, commercial, industrial, and transportation) and by the electrical power-generating sector. Traditionally, the industrial sector has been a heavy consumer of natural gas. ${ }^{4}$ For instance, in 1950 it accounted for nearly 60 percent of total natural gas consumption. ${ }^{5}$ The next highest enduser was the residential sector (20.8 percent), followed by the commercial (6.7 percent) and transportation (2.2 percent) sectors. (See Table 1 for sector descriptions and definitions.) Over time, there has been a shift in usage shares away from the industrial sector toward the commercial and electrical power generation sectors. In 1950, the

4 Consumption by establishments engaged primarily in processing unfinished materials into another form of product; this includes mining, petroleum refining manufacturing, and, beginning in 1996, agriculture, forestry, and fishing.

5 Excluding the electric power sector (the "end-use" sectors), industrial consumption usage was nearly 67 percent of all end-usage in 1950. By 2004, its end-usage share had dropped to 49.5 percent. electric power sector accounted for about 11 percent of natural gas consumption, while the commercial sector consumed a little less than 7 percent. Since then the shares of the commercial and electrical-generation sectors have doubled, while there has been relatively little change in the share of natural gas consumed by the residential and transportation sectors. Although industrial usage still accounts for the largest share of total consumption in 2004, its share has declined by more than a third.

One of the purposes of this article is to assess whether changes in natural gas prices help to predict changes in the growth of manufacturing and aggregate output and whether changes in gas prices matter more than changes in crude oil prices. This is difficult to accomplish because energy consumption by industry is not available on a timely basis. However, the EIA periodically surveys manufacturers about their energy use. This is known as the Manufacturing Energy Consumption Survey (MECS).

According to the 2002 (latest) MECS, six industries accounted for a little more than 83 percent, or 5,400 trillion BTU, of the roughly 6,500 trillion BTU of natural gas consumed by manufacturers in 2002: chemicals, petroleum and coal products, primary metals, food, paper, and 


\section{Table 2}

\section{Percentage of BTU Usage in the Manufacturing Sector Derived from Natural Gas (in trillion BTU)}

\begin{tabular}{|c|c|c|c|c|c|}
\hline NAICS code & Subsector and industry & Total* & Natural gas $^{\dagger}$ & $\begin{array}{c}\text { Gas BTU } \\
\text { as a } \% \text { of total }\end{array}$ & $\begin{array}{c}\text { Importance in } \\
\text { industrial } \\
\text { production }\end{array}$ \\
\hline 311 & Food & 1,123 & 582 & 51.83 & 8.32 \\
\hline 312 & Beverage and tobacco products & 105 & 46 & 43.81 & 2.64 \\
\hline 313 & Textile mills & 207 & 75 & 36.23 & 0.62 \\
\hline 314 & Textile product mills & 60 & 29 & 48.33 & 0.52 \\
\hline 315 & Apparel & 30 & 16 & 53.33 & 0.68 \\
\hline 316 & Leather and allied products & 7 & 4 & 57.14 & 0.11 \\
\hline 321 & Wood products & 377 & 57 & 15.12 & 1.58 \\
\hline 322 & Paper products & 2,363 & 504 & 21.33 & 2.77 \\
\hline 323 & Printing and related support & 98 & 46 & 46.94 & 2.09 \\
\hline 324 & Petroleum and coal products & 6,799 & 878 & 12.91 & 2.22 \\
\hline 325 & Chemicals & 6,465 & 2,307 & 35.68 & 10.38 \\
\hline 326 & Plastics and rubber products & 351 & 128 & 36.47 & 3.62 \\
\hline 327 & Nonmetallic mineral products & 1,059 & 422 & 39.85 & 2.27 \\
\hline 331 & Primary metals & 2,120 & 704 & 33.21 & 2.50 \\
\hline 332 & Fabricated metal products & 388 & 210 & 54.12 & 5.76 \\
\hline 333 & Machinery & 177 & 82 & 46.33 & 5.40 \\
\hline 334 & $\begin{array}{l}\text { Computer and electronic } \\
\text { products }\end{array}$ & 201 & 65 & 32.34 & 8.25 \\
\hline 335 & $\begin{array}{l}\text { Electrical equipment, appliances, } \\
\text { and components }\end{array}$ & 172 & 53 & 30.81 & 2.12 \\
\hline 336 & Transportation equipment & 429 & 203 & 47.32 & 10.91 \\
\hline 337 & Furniture and related products & 64 & 25 & 39.06 & 1.69 \\
\hline 339 & Miscellaneous manufacturing & 71 & 32 & 45.07 & 3.24 \\
\hline
\end{tabular}

NOTE: *"Total" is the sum of all of the listed energy sources, including "miscellaneous manufacturing," minus the shipments of energy sources produced onsite. It is the total amount of first use of energy for all (fuel and nonfuel) purposes. ${ }^{+}$Natural gas" includes natural gas obtained from utilities, local distribution companies, and any other suppliers, such as independent gas producers, gas brokers, marketers, and any marketing subsidiaries of utilities. ${ }^{*}$ Relative importance estimates the contribution of the industry to the growth of total industrial production in the following year.

SOURCE: U.S. Energy Information Administration, 2002 Energy Consumption by Manufacturers (Table 1.2) (www.eia.doe.gov/emeu/ mecs/mecs2002/data02/shelltables.html) and Board of Governors of the Federal Reserve System (industrial production data).

nonmetallic mineral products (see Table 2). The chemical industry consumed the most natural gas (2,307 trillion), accounting for about 36 percent of the total manufacturing BTU usage. The next largest user, petroleum and coal products, used about a third as much natural gas as the chemical industry. In terms of their relative importance, these industries accounted for about 30 percent of total industrial production in 2005. Table 2 also shows that there are four industries that derive at least 50 percent of their energy demand from natural gas: leather and allied products, fabricated metal products, apparel, and food. However, these four gas-intensive industries combined 


\begin{tabular}{|c|c|c|c|}
\hline NAICS code & Manufacturing industry & 2002 share & 1998 share \\
\hline 311 & Food & 0.55 & 0.39 \\
\hline 312 & Beverage and tobacco products & 0.19 & 0.14 \\
\hline 313 & Textile mills & 0.76 & 0.59 \\
\hline 314 & Textile product mills & 0.40 & 0.28 \\
\hline 315 & Apparel & 0.19 & 0.13 \\
\hline 316 & Leather and allied products & 0.30 & 0.16 \\
\hline 321 & Wood products & 0.31 & 0.24 \\
\hline 322 & Paper products & 1.36 & 0.99 \\
\hline 323 & Printing and related support & 0.24 & 0.17 \\
\hline 324 & Petroleum and coal products & 1.44 & 1.57 \\
\hline 325 & Chemicals & 1.62 & 1.37 \\
\hline 326 & Plastics and rubber products & 0.37 & 0.27 \\
\hline 327 & Nonmetallic mineral products & 1.86 & 1.39 \\
\hline 331 & Primary metals & 2.06 & 1.62 \\
\hline 332 & Fabricated metal products & 0.42 & 0.33 \\
\hline 333 & Machinery & 0.17 & 0.13 \\
\hline 334 & Computer and electronic products & 0.10 & 0.05 \\
\hline 335 & Electrical equipment, appliances, and components & 0.25 & 0.15 \\
\hline 336 & Transportation equipment & 0.13 & 0.11 \\
\hline 337 & Furniture and related products & 0.17 & 0.16 \\
\hline \multirow[t]{3}{*}{339} & Miscellaneous manufacturing & 0.13 & 0.15 \\
\hline & Total & 0.64 & 0.49 \\
\hline & Average wellhead price, \$ per thousand cubic feet & 2.95 & 1.96 \\
\hline
\end{tabular}

SOURCE: U.S. Energy Information Administration (energy expenditures data) and the U.S. Department of the Census (manufacturing shipments data).

account for a much smaller share of industrial production, about 15 percent.

Table 3 provides an alternative method of measuring the intensity of natural gas usage. This table shows the dollar value of the industry's total expenditures on natural gas as a percent of its total shipments in the 2002 and 1998 MECS years. Recall from Table 2 that the three most gas-intensive industries were leather and allied products, fabricated metal products, and apparel. Each of these three industries relies on natural gas for more than 50 percent of its total BTU usage. As shown in Table 3, though, the three most gas- intensive industries in 2002 were primary metals, nonmetallic mineral products, and chemicals. The paper and petroleum and coal products industries were the only other industries where expenditures were more than 1 percent of total industry shipments in 2002. Compared with 1998, expenditures on natural gas as a share of shipments for all industries rose from about 0.5 percent to 0.6 percent, even though the nominal price of natural gas rose by slightly more than 50 percent. Still, as a percent of total shipments, expenditures on natural gas are fairly small for all manufacturing industries. 


\section{ENERGY PRICES AND THE MACROECONOMY}

Economic theory predicts that a large increase in the relative price of energy will increase the per-unit cost of output, thus increasing the output (supply) price. Hence, in the standard textbook model (for example, see Abel and Bernanke, 2005), a rise in energy prices, in the absence of a fiscal or monetary policy response, reduces aggregate output and employment and raises the price level. One rule of thumb is that a $\$ 10$ per barrel rise in oil prices will reduce real GDP by 0.4 percent after four quarters. ${ }^{6}$ As an important energy input in the U.S. economy, increases in natural gas prices would be expected to have virtually the same effect in the textbook model as a rise in crude oil prices. Accordingly, one should expect that the effects of an increase or decrease in natural gas prices on economic activity would be conceptually similar as that for crude oil prices.

\section{Oil Price Effects}

There is much research that explores the relationship between energy prices and economic activity, and a reading of this literature suggests that oil prices matter. This should probably not be surprising given that petroleum still accounts for 40 percent of U.S. energy usage. The prevailing view is that increases in oil prices reduce real GDP growth for several quarters. The size of the effect varies, but earlier studies seem to suggest larger effects than later studies. This could reflect the fact that the U.S. economy has become more energy efficient over time. ${ }^{7}$

For a recent survey, see Jones, Leiby, and Paik (2004). Hamilton (1983), among many others, has documented a negative and significant relation between oil price changes and future GDP growth. Early research efforts by the Energy Modeling Forum at Stanford University (1987), which employed several well-known macroeconomic forecasting models in use at the time, were consistent with Hamilton's findings. Conversely,

\footnotetext{
${ }^{6}$ See Council of Economic Advisers (2005, p. 32).

7 Energy consumption per unit of GDP (thousands of BTU per one dollar of real GDP) declined by 41 percent from 1979 to 2004 .
}

recent research by Barsky and Kilian (2004) suggest that the causality runs in the other direction. That is, stronger (weaker) macroeconomic growth increases (decreases) the demand for oil and thus the price of oil.

Hooker (1996) found that Hamilton's result breaks down after 1986, a year in which, perhaps not coincidentally, there was a sharp, unexpected drop in oil prices. The unstable oil-macroeconomy relation possibly reflected the fact that Hamilton had implicitly assumed a symmetric effect of oil shocks in his linear specification: An increase (decrease) in oil prices reduces (raises) future GDP growth. This specification is consistent with the view of some transmission channels-for example, Rasche and Tatom (1977a,b), Baily (1981), Energy Modeling Forum (1987), and Wei (2003). ${ }^{8}$

However, the effect can be also asymmetric. In particular, a sharp oil price change-either increase or decrease-affects the macroeconomy adversely for at least two reasons. First, it raises uncertainty about future oil prices and thus causes delays in business investment (e.g., Bernanke, 1983, and Pindyck, 1991). Similarly, Guo and Kliesen (2005) found that oil price volatility-a measure of uncertainty-reduced real GDP growth and other measures of macroeconomic activity over the period 1984-2004. Second, it induces costly resource reallocations (e.g., Lilien, 1982, and Hamilton, 1988). Overall, whereas an oil price increase has a negative effect on future GDP growth, the effect of an oil price decrease is ambiguous. Subsequent work by Hamilton (1996 and 2003) revealed asymmetries with respect to oil price changes and real GDP growth.

\section{Natural Gas Price Effects}

The literature examining the relationship between natural gas prices and macroeconomic activity appears to be considerably more sparse. However, because natural gas consumption in the aggregate economy is about half as much as petroleum (in terms of BTU), it might be reasonable to conclude that rising natural gas prices might have smaller aggregate effects than do oil prices. Early

8 Also see Jones, Leiby, and Paik (2004) for discussion on various transmission channels of oil shocks. 
work in this area appeared in a special issue of the October 1982 Contemporary Policy Issues. There were three papers in this issue that studied the effects of lifting natural gas price controls (i) on regional economic activity (Leone, 1982), (ii) on the distribution of income between households and suppliers (Stockfisch, 1982), and (iii) on inflation (Ott and Tatom, 1982a). The general conclusion of the papers was that the presumed effects of natural gas decontrol (higher prices, higher inflation, and falling real incomes) were not expected to be significant. According to the Energy Modeling Forum (1987), a 10 percent increase in natural gas prices was found to have roughly the same effect on real GDP growth (two years after the shock) as a 20 percent increase in oil prices. According to the median result of 11 models, a 50 percent oil shock reduced real gross national product by about 1.5 percent after one year and by a little less than 3 percent by the end of two years. ${ }^{9}$ At the disaggregated level, Cullen, Friedberg, and Wolfram (2005) studied the effects of anticipated and unanticipated shocks to household disposable income arising from increased energy expenditures on household consumption. They found that increases in energy prices reduce consumption among lower-income households, but only when the increase is unanticipated.

More recently, the Energy Modeling Forum at Stanford University hosted a conference in December 2005: "World Natural Gas Markets and Trade." According to an Economics and Statistics Administration (2005) study prepared for the U.S. Congress, a permanent $\$ 1$ increase in natural gas prices (wellhead price) over the period 2000-04 reduced real GDP growth by 0.1 percentage points per year. ${ }^{10}$ Studies by Global Insight and Oxford Economics Forecasting were cited as showing similar results.

However, because some manufacturing industries are more natural gas-intensive than others, it

\footnotetext{
9 Using a general-equilibrium framework, Guerrieri (2005) found that a 50 percent permanent increase in the price of oil reduced U.S. real GDP growth by 0.6 percent after one year and 1.9 percent after two years (relative to the baseline forecast).

10 The study used an interindustry model of the U.S. economy developed at the University of Maryland (INFORUM LIFT); www.stanford.edu/group/EMF/projects/emf23/Henry.pdf.
}

is possible that the disaggregated effects are more significant. The next section examines this issue.

\section{EMPIRICAL ANALYSIS}

This analysis will test whether higher natural gas prices predict the growth of U.S. manufacturing output and real GDP: Aggregate manufacturing output will be measured using the manufacturing component of the industrial production (IP) index; the disaggregated measures are IP output at the three-digit NAICS level for all manufacturing industries. ${ }^{11}$ The IP indices are published monthly by the Federal Reserve Board of Governors. The natural gas price data series used in the empirical analysis is the producer price index (PPI) for natural gas, which is a commodity index published monthly by the Bureau of Labor Statistics. One potential shortcoming of this approach is that natural gas prices paid can vary significantly across industries. For example, the 2002 MECS found that the average price paid by three-digit NAICS industries varied between \$3.37 and \$5.47 per million BTU; the standard deviation was $\$ 0.57$ per million BTU. Although the use of price-hedging arrangements such as fixed-price or futures markets contracts may allow some firms to pay less on average than other firms, it seems reasonable to conclude that, eventually, all firms must bear price increases or decreases based on market trends.

The empirical analysis will follow the general form of a simple least-squares regression:

$$
\Delta \ln \left(X_{t}\right)=a_{t}+\sum_{i=1}^{n}\left[b_{i} \Delta \ln \left(X_{t-i}\right)+c_{i} \Delta \ln \left(P_{t-i}\right)\right]+\varepsilon_{t},
$$

where $a_{t}$ is a constant, $X_{t}$ is output, and $P_{t}$ is the PPI measure of natural gas prices. The maximum lag length is set to 12 for the monthly analysis and 4 for the quarterly analysis, and the optimum lag length is determined by using the Akaike information criterion (AIC) statistic. The sample period begins in January 1979, which immediately fol-

\footnotetext{
${ }^{11}$ Total industrial production also includes output produced by mines and utilities. Thus, the analysis presented in this paper excludes the effects of higher natural gas prices on these sectors.
} 


\section{Table 4}

\section{Do Changes in Natural Gas Prices Affect the Industrial Sector?}

\begin{tabular}{|c|c|c|c|}
\hline IP sector & Lags (AIC) & Sum of $c_{i}$ coefficient & $p$-Value \\
\hline Manufacturing & 3 & 0.0033 & 0.862 \\
\hline Food & 1 & 0.0013 & 0.709 \\
\hline Beverages and tobacco products & 2 & 0.0232 & 0.419 \\
\hline Textile mills & 12 & -0.0499 & 0.416 \\
\hline Textile product mills & 9 & -0.0381 & 0.844 \\
\hline Apparel & 4 & 0.0276 & 0.284 \\
\hline Leather and allied products & 4 & 0.0379 & 0.255 \\
\hline Wood products & 1 & -0.0031 & 0.791 \\
\hline Paper products & 3 & -0.0091 & 0.791 \\
\hline Printing and related support activities & 4 & 0.0062 & 0.920 \\
\hline Petroleum and coal products & 2 & -0.0063 & 0.256 \\
\hline Chemicals & 1 & -0.0033 & 0.519 \\
\hline Plastics and rubber products & 1 & -0.0030 & 0.612 \\
\hline Nonmetallic mineral products & 3 & 0.0186 & 0.192 \\
\hline Primary metals & 2 & -0.0170 & 0.614 \\
\hline Fabricated metal products & 3 & -0.0007 & 0.800 \\
\hline Machinery & 6 & -0.0254 & 0.148 \\
\hline Computers and electrical products & 6 & -0.0158 & 0.371 \\
\hline Electrical equipment, appliances, and components & 12 & -0.0372 & 0.841 \\
\hline Transportation equipment & 1 & -0.0063 & 0.61 \\
\hline Furniture and related products & 2 & $-0.0155^{*}$ & 0.077 \\
\hline Miscellaneous manufacturing & 3 & -0.0031 & 0.742 \\
\hline
\end{tabular}

NOTE: The table reports the general form of the model that was run over the period January 1979 to February 2006:

$$
\Delta \ln \left(I_{-} \text {Sector }_{t}\right)=a_{t}+\sum_{i=1}^{n}\left[b_{i} \Delta \ln \left(I_{-} \text {Sector }_{t-i}\right)+c_{i} \Delta \ln \left(P P I_{-} \text {NatGas }_{t-i}\right)\right]+e_{t} .
$$

$I P$ is industrial production (total and individual industry), and PPI_NatGas is the producer price index for gas fuels. The $p$-values are from the test of the null that all of the lags of PPI_NatGas are equal to zero. The optimum lag length chosen by the AIC statistic. For the reported $p$-values, ${ }^{* * *}, * *$, and $*$ denote significance at the 1,5 , and 10 percent levels, respectively.

lows the commencement of U.S. natural gas deregulation, and extends through February 2006.

The results are reported in Table $4 .{ }^{12}$ Each row reports the results of separate regressions for total manufacturing output and industry output at the three-digit NAICS level. Following Hamilton

\footnotetext{
${ }^{12}$ In results not reported here, the growth of U.S. manufacturing output (log change) was regressed on a constant, the growth (log change) in natural gas prices, and its coefficient was positive and not significantly different from zero. In fact, the adjusted $\mathrm{R}^{2}$ of the equation was negative. This regression was subsequently augmented (i) with last period's output growth and (ii) by cyclical changes in
}

(2003), the table regresses contemporaneous output growth (log change) on an equal number of its lags and lags in the log change in natural gas prices. As Hamilton showed, even though the individual coefficients of the lagged energy prices may not be significantly different from zero, collectively they may be significantly different from

economic activity, as measured by the unemployment rate. The adjusted $\mathrm{R}^{2}$ of the final specification was only about 20 percent. For brevity, the results are not published here, but are available from the author. 
Figure 3

\section{Hamilton Transformations of Petroleum and Natural Gas Prices (36 months)}

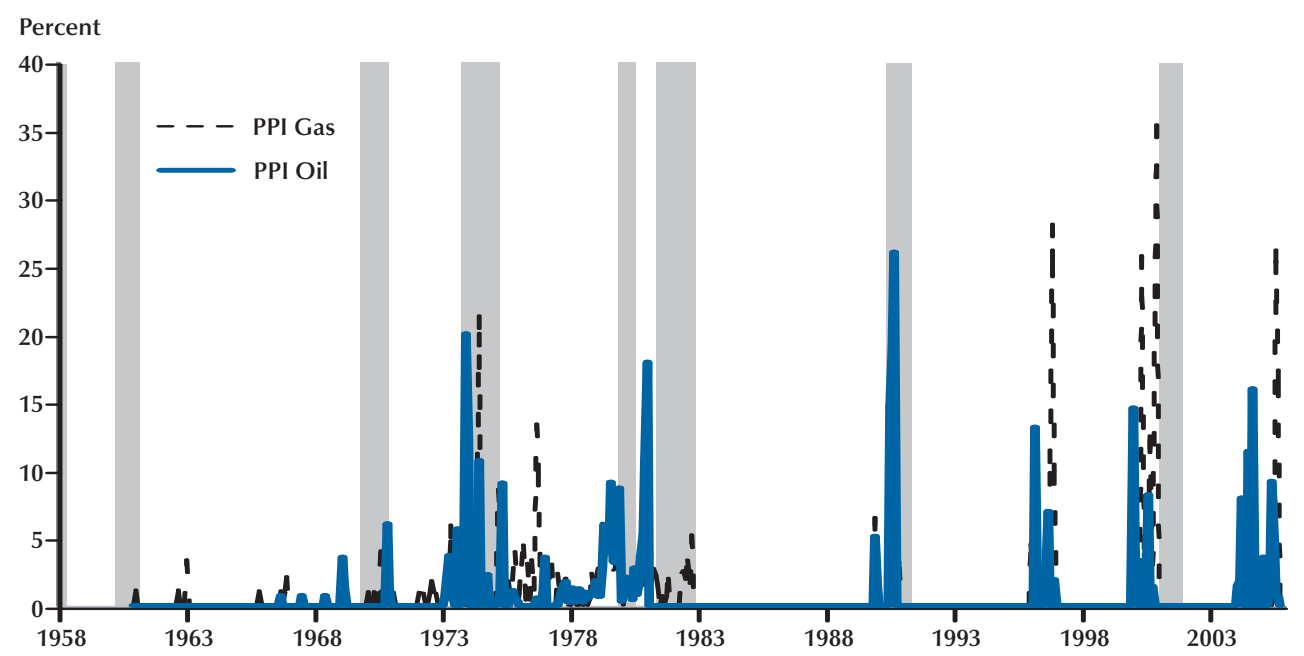

NOTE: Shaded bars indicate recessions.

zero. ${ }^{13}$ As indicated by the $p$-value, a simple F-test is used to determine whether the sum of the coefficients on the natural gas prices is significantly different from zero.

The results in Table 4 are revealing. First, changes in natural gas prices do not significantly predict total manufacturing output. Although the sum of the coefficients in the aggregate regression is positive, it is not significantly different from zero. Second, regressions at the three-digit NAICS level reveal that the furniture and related products sector is the only industry where changes in natural gas prices help to predict output growth. In this case, the sum of the coefficients is negative, as expected, and significant at the 10 percent level. The other regressions in Table 4 suggest that changes in natural gas prices do not help to predict output growth for the remaining industries. In fact, the sum of the coefficients for 6 of the 21 industries is positive, with 12 of the industries reporting $p$-values greater than 0.5 .

${ }^{13}$ This amounts to running a constrained and unconstrained regression (with and without the lags on natural gas prices).

\section{Using An Alternative Measure of Natural Gas Prices}

Hamilton (2003) showed that an asymmetric measure of oil prices helps explain real GDP growth. To test whether there are similar asymmetries with respect to natural gas prices, this article constructs two transformations of monthly natural gas prices that are consistent with his findings. The first is the percentage difference in the maximum price (log) over the most recent 12 months. The second uses a 36-month interval. If the percentage difference is negative, that month's observation is arbitrarily set to zero. Thus, in the Hamilton framework, only energy price increases matter; energy price decreases do not matter. Figure 3 plots the transformation for crude oil and natural gas prices for the 36-month interval. The figure shows that price increases for crude oil tend to be larger before 1990, while natural gas price increases tend to be larger after 1990.

Tables 5 and 6 attempt to assess whether Hamilton's transformations for natural gas and crude oil prices help to explain growth of manufacturing output at the aggregate and disaggregated level. Table 5 uses Hamilton's price changes over 


\section{Table 5}

\section{Do Increases in Crude Petroleum and Natural Gas Prices Affect Manufacturing Activity? A Test Using Hamilton's 12-Month Specification}

\begin{tabular}{|c|c|c|c|c|c|c|}
\hline \multirow[b]{2}{*}{ IP sector } & \multicolumn{3}{|c|}{ Crude petroleum } & \multicolumn{3}{|c|}{ Natural gas } \\
\hline & Lags $(\mathrm{AIC})^{\dagger}$ & $\begin{array}{c}\text { Sum of } c_{i} \\
\text { coefficient }\end{array}$ & $p$-Value & Lags $(\mathrm{AIC})^{+}$ & $\begin{array}{l}\text { Sum of } c_{i} \\
\text { coefficient }\end{array}$ & $p$-Value \\
\hline Manufacturing & 3 & -0.0206 & 0.535 & 4 & -0.0099 & 0.555 \\
\hline Food & 1 & 0.0150 & 0.190 & 1 & 0.0027 & 0.707 \\
\hline Beverages and tobacco products & 7 & 0.0348 & 0.113 & 2 & 0.0070 & 0.803 \\
\hline Textile mills & 12 & -0.1079 & 0.176 & 12 & $-0.0592^{* *}$ & 0.035 \\
\hline Textile product mills & 4 & $-0.1498^{*}$ & 0.057 & 9 & -0.0583 & 0.336 \\
\hline Apparel & 4 & 0.0000 & 0.656 & 5 & -0.0427 & 0.149 \\
\hline Leather and allied products & 6 & -0.0017 & 0.114 & 7 & -0.0849 & 0.172 \\
\hline Wood products & 10 & $-0.2520^{* *}$ & 0.040 & 7 & -0.0319 & 0.945 \\
\hline Paper products & 3 & -0.0147 & 0.554 & 6 & $-0.0787^{* *}$ & 0.027 \\
\hline Printing and related activities & 4 & -0.0312 & 0.276 & 4 & -0.0263 & 0.631 \\
\hline Petroleum and coal products & 2 & $-0.0946^{* * *}$ & 0.010 & 2 & -0.0103 & 0.261 \\
\hline Chemicals & 1 & -0.0109 & 0.501 & 1 & 0.0002 & 0.987 \\
\hline Plastics and rubber products & 1 & -0.0281 & 0.133 & 1 & -0.0146 & 0.217 \\
\hline Nonmetallic mineral products & 5 & $-0.1034^{* * *}$ & 0.008 & 3 & 0.0171 & 0.252 \\
\hline Primary metals & 2 & -0.0522 & 0.601 & 2 & -0.0283 & 0.514 \\
\hline Fabricated metal products & 3 & $-0.0249 *$ & 0.051 & 3 & -0.0137 & 0.656 \\
\hline Machinery & 3 & -0.009 & 0.772 & 3 & -0.0256 & 0.324 \\
\hline Computer and electrical products & 6 & -0.0077 & 0.958 & 6 & -0.0358 & 0.167 \\
\hline $\begin{array}{l}\text { Electrical equipment, appliances, } \\
\text { and components }\end{array}$ & 12 & -0.0499 & 0.877 & 12 & -0.0639 & 0.490 \\
\hline Transportation equipment & 1 & $-0.0698^{*}$ & 0.080 & 1 & -0.0307 & 0.222 \\
\hline Furniture and related products & 3 & -0.0574 & 0.121 & 2 & -0.0231 & 0.228 \\
\hline Miscellaneous manufacturing & 3 & -0.0132 & 0.716 & 3 & -0.0188 & 0.182 \\
\hline
\end{tabular}

NOTE: The table reports the general form of the two regressions (for the separate energy price series) that were run over the period January 1979 to February 2006:

$$
\Delta \ln \left(I P \_ \text {Sector } r_{t}\right)=a_{t}+\sum_{i=1}^{n}\left[b_{i} \Delta \ln \left(I_{-} \text {Sector }_{t-i}\right)+c_{i} \Delta \ln \left(H 1 . P P I_{-} \text {Energy }_{t-i}\right)\right]+e_{t} .
$$

IP is industrial production (total and individual industry), and H1.PPI_Energy is the producer price index for natural gas and domestic crude petroleum production transformed according to Hamilton (2003); the transformation period is 12 months. The $p$-values are from the test of the null that all of the lags of H1.PPI_NatGas are equal to zero. For the reported $p$-values, ${ }^{* * *},{ }^{* *}$, and ${ }^{*}$ denote significance at the 1,5 , and 10 percent levels, respectively. ${ }^{\dagger}$ The optimum lag length was chosen by the AIC statistic. 
Table 6

Do Increases in Crude Petroleum and Natural Gas Prices Affect Manufacturing Activity? A Test Using Hamilton's 36-Month Specification

\begin{tabular}{|c|c|c|c|c|c|c|}
\hline \multirow[b]{2}{*}{ IP sector } & \multicolumn{3}{|c|}{ Crude petroleum } & \multicolumn{3}{|c|}{ Natural gas } \\
\hline & Lags $(\mathrm{AIC})^{\dagger}$ & $\begin{array}{l}\text { Sum of } c_{i} \\
\text { coefficient }\end{array}$ & $p$-Value & Lags $(\mathrm{AIC})^{+}$ & $\begin{array}{l}\text { Sum of } c_{i} \\
\text { coefficient }\end{array}$ & $p$-Value \\
\hline Manufacturing & 4 & -0.0444 & 0.125 & 4 & -0.0186 & 0.365 \\
\hline Food & 1 & 0.0086 & 0.509 & 1 & 0.0000 & 0.996 \\
\hline Beverages and tobacco products & 6 & -0.0470 & 0.151 & 4 & $-0.0802^{* *}$ & 0.033 \\
\hline Textile mills & 2 & -0.0532 & 0.151 & 12 & $-0.0426^{* *}$ & 0.033 \\
\hline Textile product mills & 4 & $-0.1869 * *$ & 0.016 & 9 & -0.1159 & 0.434 \\
\hline Apparel & 4 & 0.0088 & 0.403 & 4 & -0.020 & 0.651 \\
\hline Leather and allied products & 6 & -0.0070 & 0.120 & 7 & $-0.1143^{* *}$ & 0.013 \\
\hline Wood products & 10 & $-0.3299 * *$ & 0.021 & 7 & -0.0639 & 0.631 \\
\hline Paper and products & 3 & -0.0115 & 0.659 & 10 & $-0.0623^{*}$ & 0.097 \\
\hline Printing and related support & 8 & -0.0452 & 0.358 & 4 & -0.0172 & 0.610 \\
\hline Petroleum and coal products & 2 & $-0.1157^{* * *}$ & 0.004 & 2 & -0.002 & 0.342 \\
\hline Chemicals & 1 & -0.0157 & 0.395 & 1 & 0.0049 & 0.713 \\
\hline Plastics and rubber products & 1 & -0.0343 & 0.105 & 1 & -0.0144 & 0.342 \\
\hline Nonmetallic mineral products & 5 & $-0.1478^{* * *}$ & 0.002 & 3 & 0.0091 & 0.674 \\
\hline Primary metals & 2 & -0.0534 & 0.678 & 2 & -0.0438 & 0.481 \\
\hline Fabricated metal products & 5 & $-0.0681^{* * *}$ & 0.003 & 3 & -0.0157 & 0.608 \\
\hline Machinery & 6 & -0.0637 & 0.365 & 6 & $-0.0944^{* *}$ & 0.022 \\
\hline Computers and electrical products & 6 & -0.0360 & 0.725 & 6 & $-0.0773 * *$ & 0.016 \\
\hline $\begin{array}{l}\text { Electrical equipment, appliances, } \\
\text { and components }\end{array}$ & 12 & -0.0883 & 0.412 & 12 & -0.1101 & 0.309 \\
\hline Transportation equipment & 1 & $-0.0892^{* *}$ & 0.048 & 1 & -0.0181 & 0.573 \\
\hline Furniture and related products & 9 & $-0.1564^{* * *}$ & 0.003 & 2 & -0.0296 & 0.263 \\
\hline Miscellaneous manufacturing & 3 & -0.0294 & 0.328 & 3 & $-0.0292 * *$ & 0.049 \\
\hline
\end{tabular}

NOTE: The table reports the general form of the two regressions (for the separate energy price series) that were run over the period January 1979 to February 2006:

$$
\Delta \ln \left(I P \_ \text {Sector } t_{t}\right)=a_{t}+\sum_{i=1}^{n}\left[b_{i} \Delta \ln \left(I_{-} \text {Sector }_{t-i}\right)+c_{i} \Delta \ln \left(H 3 . P P I \_ \text {Energy }_{t-i}\right)\right]+e_{t} .
$$

$I P$ is industrial production (total and individual industry) and H3.PPI_Energy is the producer price index for natural gas and domestic crude petroleum production transformed according to Hamilton (2003); the transformation period is 36 months. The $p$-values are from the test of the null that all of the lags of H3.PPI_NatGas are equal to zero. For the reported $p$-values, ${ }^{* * *},{ }^{* *}$, and ${ }^{*}$ denote significance at the 1, 5, and 10 percent levels, respectively. ${ }^{\dagger}$ The optimum lag length was chosen by the AIC statistic. 
a 12-month period, and Table 6 uses price changes over a 36-month period. The latter corresponds with the 3-year period that Hamilton used in his 2003 article. As in Table 4, Tables 5 and 6 report the number of significant lags of the natural gas variable based on the AIC criteria, as well as the sum of the coefficients of the lags. The tables also report the $p$-values for the lags at the conventional 1,5 , and 10 percent levels of significance.

Switching to the Hamilton transformation for natural gas prices produces results that are broadly consistent with the theory noted above. Table 5 shows that, for total manufacturing output, the sum of the lagged coefficients on gas prices is negative (first line); however, they are still not significantly different from zero ( $p$-value of 0.56 ). This result is essentially the same for crude oil prices. Table 5 also shows that when Hamilton's 12-month specification is used, the number of industries where increases in gas prices significantly predict industry output growth increases from one to two: textile mills and paper products. In both cases, the effects of higher gas prices linger from 6 to 12 months. Perhaps of greater interest, Table 5 also shows that there are six manufacturing industries that are significantly affected by changes in crude oil prices-three times the number that are affected by increases in natural gas prices. The sum of the coefficients on each of these industries is the expected sign.

Table 6 is an extension of Table 5. In this case, results are reported using the 36-month specification. In this specification, changes in natural gas prices have a negative effect on the growth of manufacturing output (line 1), but the $p$-value is still insignificant (0.37). Unlike Table 5, which showed comparable results for increases in oil and gas prices on total manufacturing output, the first line of Table 6 shows that the sum of the coefficients on crude oil prices $(-0.044)$ is more than twice as large as that for natural gas prices $(-0.019)$, but the $p$-value for crude oil is not significant. Another interesting difference between the results in Tables 5 and 6 is that the number of industries that are significantly affected by changes in natural gas prices increases from two to seven. As before, the sum of the coefficients is still nega- tive. Combined, these seven industries comprise about a quarter of manufacturing's total weight in IP (reported in Table 2). Also of interest, higher gas prices do not significantly help predict output growth in the three industries where expenditures on natural gas were the largest percentage of total industry shipments: primary metals, nonmetallic mineral products, and chemicals (see Table 3 ). This might explain why the aggregate effect (line 1) is not significant. As an aside, the finding for the chemical industry is particularly interesting, since it is by far the largest user of natural gas (see Table 2).

Finally, Table 6 shows that increases in crude oil prices have similar predictive effects on output when the Hamilton specification is extended to 36 months. In this case, the number of industries where increases in crude oil prices significantly predict output increases from six to seven. Again, the sum of the coefficients in each case has the expected negative sign. As with the seven industries in the previous paragraph, these seven industries also combine to comprise about a quarter of manufacturing's weight in IP.

\section{Extending the Analysis to the Aggregate Level}

The basic conclusion of the results presented in Tables 5 and 6 is that crude oil prices seem to have a more significant predictive effect for manufacturing industry output growth using Hamilton's 12-month specification, but essentially comparable effects when the specification is extended to 36 months. Table 7 reports an extended version of Hamilton's findings to assess whether this finding holds for real GDP. Hamilton (2003) found that the explanatory power of his 3-year specification for oil price increases was much more significant than the 1-year specification in explaining real GDP growth. ${ }^{14}$ Using data from the first quarter of 1979 through the fourth quarter of 2005, Table 7 shows that this is still the case: The $p$-value using Hamilton's 12-quarter specification is significant,

\footnotetext{
${ }^{14}$ Hamilton's results are based on data that begin in 1948, a much longer time series than reported here. As in Hamilton's work, Table 7 uses four lags and it adopts Hamilton's convention of using the log change in quarterly real GDP (not annualized).
} 
Table 7

Do Changes in Natural Gas Prices Matter for Real GDP Growth?

\begin{tabular}{lcc} 
Hamilton regressions: energy prices & F-Statistic & $\boldsymbol{p}$-Value \\
\hline 4-Quarter transformation & & 1.349 \\
Crude oil prices & 0.549 & 0.258 \\
Natural gas prices & & 0.701 \\
$\mathbf{1 2}$ Quarter transformation & $3.550^{* * *}$ & 0.0096 \\
Crude oil prices & 1.613 & 0.177
\end{tabular}

NOTE: The regressions present statistics from the following specification:

$$
\Delta \ln (\text { real_GDP })=a_{t}+\sum_{i=1}^{n}\left[b_{i} \Delta \ln (\text { real_GDP } t-i)+c_{i} \Delta \ln \left(P P I_{-} \text {Energy }_{t-i}\right)\right]+e_{t},
$$

where $n=4$.PPI_Energy is the producer price index for gas fuels and domestic crude petroleum production transformed according to Hamilton (2003). The model is estimated over the period 1979:Q1-2005:Q4. For the reported $p$-values, ${ }^{* * *},{ }^{* *}$, and ${ }^{*}$ denote significance at the 1,5 , and 10 percent levels, respectively.

but it is not significant for the 4-quarter transformation.

Table 7 also reports tests of whether changes in natural gas prices predict real GDP growth. The evidence presented in the table suggests that that is not the case. Unlike increases in crude oil prices, increases in natural gas prices do not significantly predict real GDP growth using either of Hamilton's specifications. These results are generally consistent with the total manufacturing results reported earlier.

\section{CONCLUSION}

In the aftermath of the disruptions caused by hurricanes Katrina and Rita, natural gas prices faced by consumers and producers rose to recordhigh levels. Because natural gas is the second most important energy source for the economy, there was widespread concern that these high prices might cause a significant slowing in the economy and among those manufacturing industries that depend heavily on natural gas as a source of energy. The analysis presented in this article offers some support for the latter contention, but only when prices are transformed according to the specification suggested by Hamilton. However, the results using Hamilton's specifications indi- cate that changes in natural gas prices do not cause significant output effects for the two manufacturers that are the most-intensive users of natural gas (primary metals and nonmetallic mineral products), although they do cause significant output effects for other, less-intensive manufacturers (such as machinery and computers and electrical products). While perhaps significant, this result must be balanced against the finding that, when the analysis is extended to the macroeconomy (real GDP), increases in crude oil prices significantly predict real GDP growth, but natural gas prices do not.

\section{REFERENCES}

Abel, Andrew B. and Bernanke, Ben S.

Macroeconomics. Fifth Edition. Boston: Pearson Addison Wesley, 2005.

Baily, Martin Neal. "Productivity and the Service of Capital and Labor." Brookings Papers on Economic Activity, 1981, 1, pp. 1-50.

Barsky, Robert B. and Kilian, Lutz. "Oil and the Macroeconomy Since the 1970s." Journal of Economic Perspectives, Fall 2004, 18(4), pp. 115-34. 
Bernanke, Ben S. "Irreversibility, Uncertainty, and Cyclical Investment." Quarterly Journal of Economics, February 1983, 98(1), pp. 85-106.

Council of Economic Advisers. Economic Report of the President. Washington, DC: U.S. Government Printing Office, February 2005.

Cullen, Julie B.; Friedberg, Leora and Wolfram, Catherine. "Do Households Smooth Small Consumption Shocks? Evidence from Anticipated and Unanticipated Variation in Home Energy Costs.” CSEM Working Paper 141, Center for the Study of Energy Markets, University of California Energy Institute, 2005.

Economics and Statistics Administration. "Impacts of Rising Natural Gas Prices on the U.S. Economy and Industries: Report to Congress.” U.S. Department of Commerce, June 29, 2005; www.esa.doc.gov.

Energy Modeling Forum. "Macroeconomic Impacts of Energy Shocks: A Summary of the Key Results," in B.G. Hickman, H.G. Huntington, and J.L. Sweeney, eds., Energy Modeling Forum Report 7. Volume 1. Stanford University/North Holland, 1987.

Guerrieri, Luca. "The Effects of Oil Shocks on the Global Economy.” Unpublished manuscript, Federal Reserve Board, 2005.

Guo, Hui, and Kliesen, Kevin L. "Oil Price Volatility and U.S. Macroeconomic Activity.” Federal Reserve Bank of St. Louis Review, November/December 2005, 87(6), pp. 669-83.

Hamilton, James D. "Oil and the Macroeconomy since World War II." Journal of Political Economy, April 1983, 91(2), pp. 228-48.

Hamilton, James D. “A Neoclassical Model of Unemployment and the Business Cycle," Journal of Political Economy, 1988, 96(3), pp. 593-617.

Hamilton, James D. “This Is What Happened to the Oil Price-Macroeconomy Relationship." Journal of Monetary Economics, 1996, 38(2), pp. 215-20.

Hamilton, James D. "What Is an Oil Shock.” Journal of Econometrics, 2003, 113(2), pp. 363-98.
Hooker, Mark A. "What Happened to the Oil PriceMacroeconomy Relationship?" Journal of Monetary Economics, 1996, 38(2), pp. 195-213.

Jones, Donald W.; Leiby, Paul N. and Paik, Inja K. "Oil Price Shocks and the Macroeconomy: What Has Been Learned Since 1996?” Energy Journal, 2004, 25(2), pp. 1-32.

Leone, Robert A. "Impact of Higher Natural Gas Prices on the Northeast Regional Economy." Contemporary Policy Issues, October 1982, 1(1), pp. 1-8.

Lilien, David M. "Sectoral Shifts and Cyclical Unemployment.” Journal of Political Economy, August 1982, 90(4), pp. 777-93.

Ott, Mack and Tatom, John A. "Are There Adverse Inflation Effects Associated with Natural Gas Decontrol?" Contemporary Policy Issues, October 1982a, (1), pp. 27-46.

Ott, Mack and Tatom, John A. "A Perspective on the Economics of Natural Gas Decontrol.” Federal Reserve Bank of St. Louis Review, November 1982b, 64(9), pp. 19-31.

Pindyck, Robert. "Irreversibility, Uncertainty, and Investment.” Journal of Economic Literature, September 1991, 29(3), pp. 110-48.

Rasche, Robert H. and Tatom, John A. "The Effects of the New Energy Regime on Economic Capacity, Production, and Prices." Federal Reserve Bank of St. Louis Review, May 1977a, 59(5), pp. 2-12.

Rasche, Robert H. and Tatom, John A. "Energy Resources and Potential GNP.” Federal Reserve Bank of St. Louis Review, June 1977b, 59(6), pp. 10-24.

Stockfisch, J.A. "The Income Distribution Effects of a Natural Gas Price Increase.” Contemporary Economic Policy Issues, October 1982, 1(1), pp. 9-26.

United States Energy Information Administration. Annual Energy Review 2004, U.S. Department of Energy, August 2005. 


\section{Kliesen}

Wei, Chao. "Energy, the Stock Market, and the PuttyClay Investment Model." American Economic

Review, March 2003, 93(1), pp. 311-23.

Yang, Jai-Hoon. "The Nature and Origins of the U.S. Energy Crisis." Federal Reserve Bank of St. Louis Review, July 1977, 59(7), pp. 2-12. 